\title{
Uterine enzyme changes in thyroidectomized rats at parturition
}

\author{
P. M. Rao and J. N. Panda \\ Experimental Physiology Laboratory, Division of Physiology \& Climatology, \\ Indian Veterinary Research Institute, Izatnagar-243122, India
}

\begin{abstract}
Summary. Rats were thyroidectomized at different stages of gestation and killed at parturition. Acid phosphatase of uterine horns was significantly $(P<0.05)$ lower in animals thyroidectomized at later stages of pregnancy, whereas alkaline phosphatase was significantly lower in those thyroidectomized earlier as compared to intact pregnant animals. The activities of glutamic oxaloacetic acid and glutamic pyruvic acid transaminases also showed significant alterations in some of the thyroidectomized animals. These 4 enzymes were also studied in the cervix but the changes showed a less distinct pattern.
\end{abstract}

\section{Introduction}

Maternal hypothyroidism during pregnancy has been shown to cause prolonged gestation (Lucas, Brunsted \& Fowler, 1958), reduced litter size and fetal weight (Parrot, Johnston \& Durbin, 1960; Stempak, 1962), fetal resorption and retarded fetal growth (Chu, 1944). The role of thyroid hormones for fetal growth and differentiation remains unclear (Kohler, Wojnorowich \& Emhke, 1974) although they are believed to be indispensable for the successful outcome of pregnancy (Krohn \& White, 1950; Bakshi, 1978). The uterine environment for all stages of fetal development and survival to term is important. The activities of uterine acid and alkaline phosphatases associated with implantation (Finn \& Hinchliffe, 1964; Manning, Meli \& Steinetz, 1966; Murdoch, 1970), embryo growth and survival, uterine carbohydrate metabolism (Fahmy, 1957) and glycogen deposition (Christie, 1966) have been studied, but there have been no detailed biochemical studies on the uterus as affected by hypothyroidism during pregnancy. The present investigation was designed to study the effect of hypothyroidism on pregnancy and on some uterine enzymes at parturition.

\section{Materials and Methods}

Adult female rats of the IVRI strain, weighing 180-200 $\mathrm{g}$ and of approximately the same age, were maintained at $23-27^{\circ} \mathrm{C}$ in a lighting schedule of $14 \mathrm{~h}$ light $/ 24 \mathrm{~h}$. Food and water were always available. Rats at pro-oestrus, detected from the vaginal smear, were placed with a proven male in the evening and the presence next morning of spermatozoa in the vaginal smear was considered to indicate Day 1 of pregnancy. The animals were thyroidectomized surgically (Ducommun, 1962) under ether anaesthesia by separating the recurrent laryngeal nerve from the thyroid capsule and removing both the thyroid lobes with the isthmus. All the animals were given $1 \%$ calcium gluconate solution in drinking water to combat the effects of partial para- 
thyroidectomy. After death, the operation site was examined histologically and only those animals which showed complete absence of thyroid tissue in the surrounding area were considered in the results.

Rats in Group 4 were thyroidectomized before being placed with males. The other rats were thyroidectomized at different stages of gestation corresponding to the period of zygote transport (Days 3-4: Group 5), implantation (Days 6-7: Group 6), and various stages of fetal growth (Day 8 (Group 7), Day 10 (Group 8) and Day 13 (Group 9)). Groups 1 and 2 consisted of intact and thyroidectomized non-pregnant rats killed at dioestrus. Group 3 contained intact rats killed at parturition.

The animals were examined every $2 \mathrm{~h}$ for parturition. Immediately after parturition, the uteri were removed, placed on ice and quickly frozen to $-20^{\circ} \mathrm{C}$ until homogenized with ice-cold physiological saline $(9 \mathrm{~g} \mathrm{NaCl} / 1)$, centrifuged and the supernatant taken for assay of the activities of alkaline (EC 3.1.3.1) and acid (EC 3.1.3.2) phosphatases (King \& King, 1954); glutamic oxaloacetic acid (GOT, EC 2.6.1.1) and glutamic pyruvic acid (GPT, EC 2.6.1.2) transaminases (Reitman \& Frankel, 1957) and protein (Lowry, Rosebrough, Farr \& Randall, 1951). Tissue concentrations of cholesterol (Zak, 1965) and ascorbic acid (Roe, 1957) were estimated in whole homogenate and glycogen was determined by the method of Seifter, Dayton, Noric \& Muntoyler (1950). Enzyme activities were studied in the uterine horns and the cervix, i.e. the cervical region of the duplex uterus.

Whole uterine homogenates were studied after a preliminary study showing that results for the endometrium and whole uterus were similar when calculated as activity per minute or incubation period $/ \mathrm{mg}$ soluble protein (Table 1 ).

Table 1. Enzyme activities (mean \pm s.e.m.) of endometrium and whole uterus at parturition of rats

\begin{tabular}{|c|c|c|c|c|c|}
\hline \multirow[b]{2}{*}{ Enzymes } & \multirow{2}{*}{$\begin{array}{l}\text { No. of } \\
\text { rats }\end{array}$} & \multicolumn{2}{|c|}{ Intact pregnant animals } & \multicolumn{2}{|c|}{ Thyroidectomized pregnant animals* } \\
\hline & & Endometrium & Whole uterus & Endometrium & Whole uterus \\
\hline Alkaline phosphatase & 4 & $161 \cdot 03 \pm 21 \cdot 38$ & $152.31 \pm 11.81$ & $85.09 \pm 6.50$ & $82.91 \pm 7.68$ \\
\hline Acid phosphatase & 4 & $65 \cdot 32 \pm 6 \cdot 18$ & $59 \cdot 31 \pm 7.26$ & $63 \cdot 18 \pm 9 \cdot 20$ & $66 \cdot 23 \pm 8.07$ \\
\hline GOT & 4 & $27.01 \pm 2.56$ & $29.02 \pm 4.31$ & $30 \cdot 52 \pm 3 \cdot 18$ & $28 \cdot 12 \pm 3.03$ \\
\hline GPT & 4 & $14.52 \pm 3.07$ & $16 \cdot 20 \pm 1 \cdot 11$ & $29.08 \pm 2.12$ & $27 \cdot 11 \pm 2 \cdot 18$ \\
\hline
\end{tabular}

Phosphatases expressed in $\mathrm{m}$ units/incubation period/mg soluble protein. Transaminases expressed in nmol pyruvate formed $/ \mathrm{min} / \mathrm{mg}$ soluble protein.

* On Day 3 of pregnancy.

\section{Results}

The results are shown in Text-fig. 1 and Table 2.

Uterine horns. Animals in Groups 2 and 3 had higher levels of acid and alkaline phosphatase activities than did animals in Group 1. Acid phosphatase activities were reduced in animals thyroidectomized during pregnancy but alkaline phosphatase activities were generally higher than those of animals thyroidectomized before pregnancy (Group 4). There was no obvious pattern in changes of GOT and GPT activities.

Glycogen and cholesterol concentrations were variably affected. All the treatments reduced ascorbic acid levels below that for Group 1 animals.

Cervix. Thyroidectomy and pregnancy separately caused an increase in alkaline phosphatase activities but both together in Group 4 led to a considerable reduction. Thyroidectomy during pregnancy had a variable effect. Trends similar to those in the uterus were observed for the GOT and GPT activities of the cervix (Text-fig. 1).

Glycogen and cholesterol changes were not pronounced but ascorbic acid levels were lower in the pregnant than in the non-pregnant animals. 


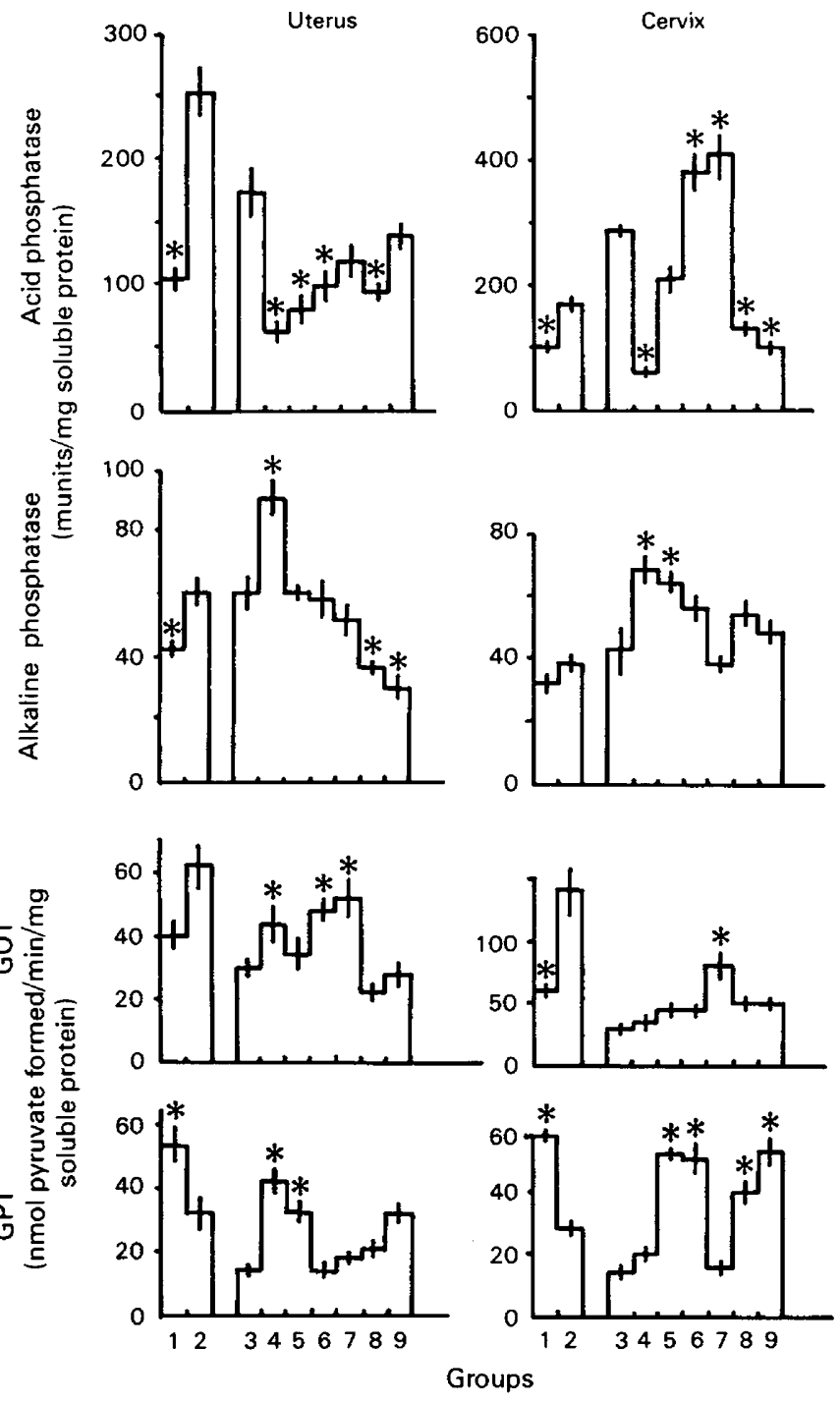

Text-fig. 1. The changes in activity of alkaline and acid phosphatases and GOT and GPT in the uterus and cervix of rats in Groups 1-9 (see text) for treatments of animals. Values are mean \pm s.e.m. for the numbers of rats indicated in Table $2 ;{ }^{*}$ indicates values significantly different $(P<$ 0.05 ) from the value for Group 3.

\section{Discussion}

These results show that there are differences at parturition for some uterine substances in hypothyroidic and normal animals.

Acid phosphatase activity in the uterus has been reported tc increase during pregnancy in the ewe and rabbit and has been correlated with embryo survival and development, being more important than alkaline phosphatase for the conceptus soon after the embryonic membranes establish contact with maternal tissues (Boshier, 1969; Murdoch, 1970). Jelineck \& Jelinkova (1977) demonstrated that lactate dehydrogenase increased more in the endometrium than in the myometrium during oestrus and up to the 6th day of pregnancy in the rat. In the present study 
Table 2. Some tissue biochemical constituents (mean \pm s.e.m.) of different parts of the uterus of rats thyroidectomized (Thx) during gestation

\begin{tabular}{|c|c|c|c|c|c|c|c|c|}
\hline \multirow[b]{2}{*}{ Group } & \multirow[b]{2}{*}{ Treatment } & \multirow[b]{2}{*}{$\begin{array}{l}\text { No. } \\
\text { of } \\
\text { rats }\end{array}$} & \multicolumn{3}{|c|}{ Uterine horns } & \multicolumn{3}{|c|}{ Cervix } \\
\hline & & & $\begin{array}{l}\text { Glycogen } \\
(\mathrm{g} / 100 \mathrm{~g})\end{array}$ & $\begin{array}{c}\text { Ascorbic } \\
\text { acid } \\
(\mathrm{mg} / 100 \mathrm{~g})\end{array}$ & $\begin{array}{l}\text { Cholesterol } \\
(\mathrm{mg} / 100 \mathrm{~g})\end{array}$ & $\begin{array}{l}\text { Glycogen } \\
(\mathrm{mg} / 100 \mathrm{~g})\end{array}$ & $\begin{array}{c}\text { Ascorbic } \\
\text { acid } \\
(\mathrm{mg} / 100 \mathrm{~g})\end{array}$ & $\begin{array}{l}\text { Cholesterol } \\
(\mathrm{mg} / 100 \mathrm{~g})\end{array}$ \\
\hline 1 & $\begin{array}{r}\text { Intact non- } \\
\text { pregnant } \\
\text { (control) }\end{array}$ & 8 & $3 \cdot 0 \pm 0 \cdot 1^{*}$ & $31.4 \pm 4 \cdot 1 \dagger$ & $960 \cdot 5 \pm 57 \cdot 7 \ddagger$ & $3 \cdot 1 \pm 0 \cdot 8$ & $25 \cdot 1 \pm 2 \cdot 4 \dagger$ & $755 \cdot 3 \pm 89 \cdot 0 \ddagger$ \\
\hline 2 & $\begin{array}{l}\text { Non-pregnant } \\
\text { Thx }\end{array}$ & 7 & $4 \cdot 3 \pm 0 \cdot 3$ & $18 \cdot 5 \pm 4 \cdot 5$ & $1229 \pm 29.4$ & $3 \cdot 8 \pm 0 \cdot 5$ & $28 \cdot 8 \pm 1 \cdot 4$ & $1420 \cdot 7 \pm 196.6$ \\
\hline 3 & Intact pregnant & 8 & $4.9 \pm 0.2$ & $16 \cdot 3 \pm 1.9$ & $1291.0 \pm 123 \cdot 3$ & $3.9 \pm 0.7$ & $9 \cdot 3 \pm 2 \cdot 5$ & $938.7 \pm 112.1$ \\
\hline 4 & $\begin{array}{l}\text { Thx first and } \\
\text { then pregnant }\end{array}$ & 6 & $2 \cdot 6 \pm 0.6^{*}$ & $10 \cdot 5 \pm 2 \cdot 8$ & $445 \cdot 3 \pm 46 \cdot 5$ & $1 \cdot 9 \pm 0 \cdot 2$ & $12 \cdot 4 \pm 2 \cdot 4$ & $1085 \cdot 7 \pm 30 \cdot 8$ \\
\hline 5 & $\begin{array}{l}\text { Thx on Day } 3 \\
\text { of pregnancy }\end{array}$ & 8 & $2 \cdot 8 \pm 0 \cdot 3^{*}$ & $11 \cdot 1 \pm 1 \cdot 4$ & $323 \cdot 3 \pm 29 \cdot 4$ & $3 \cdot 9 \pm 0 \cdot 3$ & $15 \cdot 6 \pm 3 \cdot 0$ & $1032 \cdot 0 \pm 97 \cdot 5$ \\
\hline 6 & $\begin{array}{l}\text { Thx on Day } 6 \\
\text { of pregnancy }\end{array}$ & 8 & $4 \cdot 8 \pm 0 \cdot 1$ & $11 \cdot 7 \pm 3 \cdot 2$ & $823.4 \pm 107 \cdot 2$ & $4.8 \pm 1.4$ & $13 \cdot 5 \pm 1 \cdot 8$ & $1172 \cdot 3 \pm 121 \cdot 1$ \\
\hline 7 & $\begin{array}{l}\text { Thx on Day } 8 \\
\text { of pregnancy }\end{array}$ & 8 & $4.9 \pm 0.1$ & $16 \cdot 3 \pm 0 \cdot 7$ & $760 \cdot 3 \pm 97 \cdot 6$ & $5 \cdot 7 \pm 0 \cdot 2$ & $14 \cdot 7 \pm 3 \cdot 2$ & $1499 \cdot 3 \pm 142 \cdot 5$ \\
\hline 8 & $\begin{array}{r}\text { Thx on Day } 10 \\
\text { of pregnancy }\end{array}$ & 7 & $2 \cdot 2 \pm 0.4^{*}$ & $15 \cdot 0 \pm 0.8$ & $976 \cdot 7 \pm 67 \cdot 9$ & $4 \cdot 1 \pm 0 \cdot 2$ & $10 \cdot 3 \pm 2 \cdot 3$ & $1149 \cdot 3 \pm 34 \cdot 5$ \\
\hline 9 & $\begin{array}{r}\text { Thx on Day } 13 \\
\text { of pregnancy }\end{array}$ & 7 & $3 \cdot 7 \pm 0 \cdot 8$ & $12 \cdot 7 \pm 2 \cdot 6$ & $1113.8 \pm 71.4$ & $2 \cdot 6 \pm 0 \cdot 1$ & $13.9 \pm 2.9$ & $1225 \cdot 0 \pm 124.9$ \\
\hline
\end{tabular}

* Significantly different from Group 3 value, $P<0.01$ (Student's $t$ test).

$\dagger$ Significantly different from Group 3 value, $P<0.05$ (Student's $t$ test).

‡ Significantly different from Group 2 value, $P<0.05$ (Student's $t$ test).

also, acid phosphatase activities were higher in pregnant than non-pregnant rats even though the activities of the enzyme were studied at the end of gestation. Thyroidectomy during pregnancy led to reduced activity in the uterine horns only after Day 10. Increased alkaline phosphatase values have been associated with implantation (Finn \& Hinchliffe, 1964; Manning et al. 1966), carbohydrate metabolism (Fahmy, 1957) and glycogen deposition in the pregnant uterus (Christie, 1966). In this study the alkaline phosphatase activity was higher in the uterine horn and cervix of the pregnant than of the non-pregnant animals but thyroidectomy during gestation led to lower levels in most of the experimental groups.

The transaminases (GOT and GPT) and phosphomonoesterases are concerned with cellular transfer systems, protein \& nucleic acid synthetic processes and energy producing mechanisms (Bradfield, 1950; Bartley, Birt \& Banks, 1968). In non-pregnant animals, thyroidectomy caused a significant rise in GOT and fall in GPT activities in the uterine horns and the cervix. Significant alterations in transaminase activities in uterine horns of animals thyroidectomized at earlier stages of pregnancy indicated the influence of thyroid hormone on the cellular functions attributed to these enzymes. In the cervix GOT activities changed little in response to thyroidectomy in pregnancy but GPT was mostly increased.

Glycogen starts accumulating at the site of implantation in greater amounts to serve as a source of nutrition to the embryo in rat (Christie, 1966). Increased glycogen levels were found in the uterine horns of the intact pregnant compared to those of normal non-pregnant rats and thyroidectomy at various stages of gestation caused significant reductions only in a few groups. Pregnancy and hypothyroidism during gestation had little effect on the glycogen content of the cervix. Impaired fetal growth in the hypothyroidic mothers observed in this study (Rao \& Panda, 1980) may be due to the alterations in glycogen metabolism or transplacental CHO transport (Porterfield, Egerton \& Chester, 1975).

Tissue concentration of ascorbic acid is often said to bear a positive correlation with its 
metabolic activities (White, Handler \& Smith, 1975). A significant decrease in ascorbic acid concentrations was noted in the uterine horns and the cervix in intact pregnant rats compared to non-pregnant animals and a role in the metabolic activities of the uterus during pregnancy seems doubtful. Thyroidectomy appeared to have little effect. Cholesterol forms the intrinsic component of the lipid bilayers of cell membranes and regulates the permeability to water (Graziani \& Livne, 1972) and polar (White et al., 1975) and non-polar ions (McElhaney, Gier \& Vander, 1973). The experimental treatments in this study had little effect on the cholesterol concentration in the uterine horns and cervix at parturition.

We thank Dr M. M. RazaNasir and other colleagues at I.V.R.I. for their interest and encouragement.

\section{References}

Bakshi, S.N. (1978) Effect of maternal thyroparathyroidectomy during gestation on foetoplacental development in rats. Ind. J. exp. Biol. 16, 12811283.

Bartley, W., Birt, L.M. \& Banks, P. (1968) Transport of materials and messages. In Biochemistry of Tissues, pp. 163-168. Wiley, New York.

Boshier, D.P. (1969) A histological and histochemical examination of implantation and early placentome formation in sheep. J. Reprod. Fert. 19, 51-61.

Bradfield, J.R.C. (1950) The localization of enzymes in cells. Biol. Rev. 25, 113-158.

Christie, G.A. (1966) Implantation of the rat embryo: glycogen and alkaline phosphatase. J. Reprod. Fert. 12, 279-294.

Chu, J.P. (1944) The influence of the thyroid in pregnancy and parturition in the rabbit. J. Endocr. 4, 109-114.

Ducommun, P. (1962) Note sur la thyroidectomie chirurgicale chez la Rate adulte. Revue Can. Biol. 21, 171-173.

Fahmy, A.N. (1957) Site and origin of fructose in sheep placenta. Gaz. Egypt. Soc. Gynaec. Obstet. 5, 54-57.

Finn, C. \& Hinchliffe, J.R. (1964) Reaction of the mouse uterus during implantation and decidua formation as demonstrated by changes in the distribution of alkaline phosphatase. J. Reprod. Fert. 8, 331-338.

Graziani, Y. \& Livne, A. (1972) Water permeability of bilayer lipid membranes: sterol and water interaction J. memb. Biol. 7, 275-284.

Jelineck, J. \& Jelinkova, M. (1977) Rat endometrium enzymes in 4-day oestrous cycle and early pregnancy. Acta endocr., Copenh. 85, 169-176.

King, P.R.N. \& King, E.J. (1954) Estimation of plasma phosphatase by determination of hydrolysed phenol with amino-antipyrine. J. clin. Path. 7, 322-326.

Kohler, E., Wojnorowich, F. \& Emhke, W. (1974) Effect of maternal Athyreosis on rat embryos during the late phase of organogenesis. Acta endocr., Copenh. 75, 523-530.

Krohn, P.L. \& White, H.C. (1950) The effect of hypothyroidism on reproduction in the female albino rat. J. Endocr. 6, 375-385.

Lowry, O.H., Rosebrough, N.J., Farr, A.L. \& Randall, P.J. (1951) Protein measurement with the Folin phenol reagent $J$. biol. Chem. 193, 265-276.
Lucas, J.J., Brunsted, G.E. \& Fowler, S.H. (1958) The relationship of altered thyroid activity to various reproductive phenomena in gilts. $J$. Endocr. 17, 54-61.

Manning, J.P., Meli, A. \& Steinetz, B.G. (1966) Alkaline phosphatase and B-glucuronidase activity in the rat uterus during early pregnancy. $J$. Endocr. 35, 385-391.

McElhaney, R.N., Gier, J. de \& Vander, E.C.H. (1973) The effect of alterations in fatty acid composition and cholesterol content on the non-electrolyte permeability. Biochim. Biophys. Acta 298, 500-512.

Murdoch, R.N. (1970) Uterine endometrial phosphomonoesterases in relation to implantation in the ewe and rabbit doe. Aust. J. biol. Sci. 23, 10891097.

Parrot, M.W., Johnston, M.E. \& Durbin, P.W. (1960) The effect of thyroid and parathyroid deficiency on reproduction in the rat. Endocrinology 67, 467-483.

Porterfield, S.P., Egerton, W. \& Chester, H. (1975) Hypoglycemia and glycogen deficiency in foetuses of hypothyroid pregnant rats. Proc. Soc. exp. Biol. Med. 149, 748-783.

Rao, P.M. \& Panda, J.N. (1980) Effect of hypothyroidism on pregnancy in rats. Ind. J. Physiol. Pharmac. 24, 126-130.

Reitman, S. \& Frankel, S. (1975) Enzymes in blood. In Analysis in Medical Biochemistry, 4th edn, pp. 112-114. Ed. I. D. P. Wooton. Churchill, London.

Roe, J.H. (1957) Chemical determination of ascorbic, dehydroascorbic and diketogluconic acids. In Methods of Biochemical Analysis, vol. 1, pp. 127132. Ed. D. Glick. Interscience Publishers, New York.

Seifter, S.S., Dayton, S., Noric, B. \& Muntoyler, E. (1950) The estimation of glycogen with the anthrone reagent. Arch. Biochem. 25, 191-194.

Stempak, G. (1962) Maternal hypothyroidism and its effect on foetal development. Endocrinology $\mathbf{7 0}$, 444-445.

White, A., Handler, P. \& Smith, E.L. (1975) Principles of Biochemistry, 5th edn. McGraw-Hill, New York.

Zak, B. (1965) Total and free cholesterol. In Standard Methods of Clinical Chemistry, vol. 5, pp. 79-89. Ed. S. Meites. Academic Press, New York.

Received 2 April 1980 